\title{
JOON VAN ROOY EN DIE STAATKUNDIGE LEWE.
}

Al was professor J. C. van Rooy_,,ou Joonie” soos hy vir sommige van ons was-toevallig nie regstreeks betrokke by een of ander bedrywigheid in die staatsbestuur nie, kon dit maklik anders gewees het. Sommige het immers in hom 'n moontlike Administrateur van Transvaal gesien na 1948, en 'n mens kan maar sê dat dit net naelskraap was dat hy dit nie geword het nie!

Dié feit bewys hoe na hy, nieteenstaande sy kerklike, akademiese en kulturele werksaamhede, moes gestaan het aan die nasionaalgesinde politieke leiers van sy volk, en watter hoë dunk hulle moes gehad het van sy bekwaamheid en reggesindheid. Ook kan daaruit afgelei word dat by hom meer as net belangstelling in die politieke stryd gedurende die afgelope twee tot drie dekades moes gewees het. Dit was dan ook so. Joon van Rooy was nie net nasionalis op kultuurgebied en as kieser nie. Hy het, veral in troebele dae, sy gewig - al was dit in die agtergrond en nie soseer in die aktiewe partylewe nie - vol ingegooi agter die bevordering van die Nasionale Party, en by uitstek van die beleid en die ideale van Nasionalisme.

Sy vriende en medewerkers het lankal geweet van sy diepe geesdrif vir die regte van die Afrikaanse taal, die stryd om 'n aandeel in die landsbestuur, die ekonomiese selfstandigmaking van sy land en volk, en vir die republikeinse vryheidstrewe van die Afrikanernasie. Die breë publiek het dit net af en toe agtergekom wanneer hy-meestal teen wil en dankvoorgeskuif is deur sy geesgenote om hul standpunt in die openbaar te vertolk. Hy was te beskeie om te glo dat hy die regte persoon was om dit te doen, en het dan maar met 'n sug huiwerend toegegee: „As julle dit dan so wil, moet ek seker; maar daar is mos ander wat dit beter sal kan stel."

Toe generaal Hertzog as Eerste Minister-voor die tweede wêreldoorlog-gemeen het dat 'n bekende Afrikanerorganisasie hom op ondermynende wyse wou inlaat met die landsbestuur, het dit Joon van Rooy se plig geword om die ou staatsman te oortuig dat dit die geval was nie. Soseer het hy hierin geslaag dat die generaal tot sy heengean op goeie voet met die jonger man verkeer het, en dat vertroulike gesprekke tussen hulle oor landsake nie uitgebly het nie, selfs in die moeilike jare na 1939 en tot kort voor generaal Hertzog se heengaan.

Monument-koppie! Wie onthou nie Joon van Rooy se aandeelsaam met sy vriende- om die byeenkoms (buitengewoon in die geskiedenis van enige volk) tot stand te bring nie? Wie onthou nie sy toespraak en sy 
groot vreugde oor die saamkom van staatsmanne wie se paaie eers geskei was nie? Wie onthou nie sy teleurstelling toe dit blyk dat die tyd en die gemoedere nog nie ryp was vir eenheid nie?

'n Ander voorbeeld kan geneem word uit die oorlogsjare. Toe die botsing tussen die Nasionale Party en die Ossewabrandwag ontwikkel het, was Joon van Rooy een van die wat hul uiterste ingespan het om 'n oplossing te vind. Hy het steeds opgetree as iemand wat bly by sy party. Tog was hy in sy optrede en onderhandelings so innemend, so sagsinnig, so bekommerd oor die volksaak, en so nederig dat hy die toegang tot die Ossewabrandwagleiers ook bly behou het .Vandaar dat hy toe bemiddelaar by uitnemendheid, al was dit sonder sukses, geword het. Indien dr. Malan se voorstel van 'n Nasionale Komitee te stig om alle botsings te oorbrug geslaag het - en dit sou 'n politieke komitee gewees het-sou Joon van Rooy een van die eerste lede geword het.

Só na het hierdie beskeie man van tyd tot tyd aan die hart van die politieke stryd gekom. Só nou en persoonlik, dikwels intiem, was sy aanraking met die vernaamste leiers van sy volk in die afgelope twintig jaar. Só deurdring was sy lewe en sy wese met die volksideale wat koers en rigting gegee het in die moeilike dae wat verby is. Met diepe erns het hy dan ook in die afgelope jare telkens en telkens weer die hoop uitgespreek, en openlik daarvoor gebid, dat hulle steeds die rigsnoer moet bly van dié Regering wie se oorwinnings hy met jubelende hart verwelkom het.

H. F. VERWOERD. 